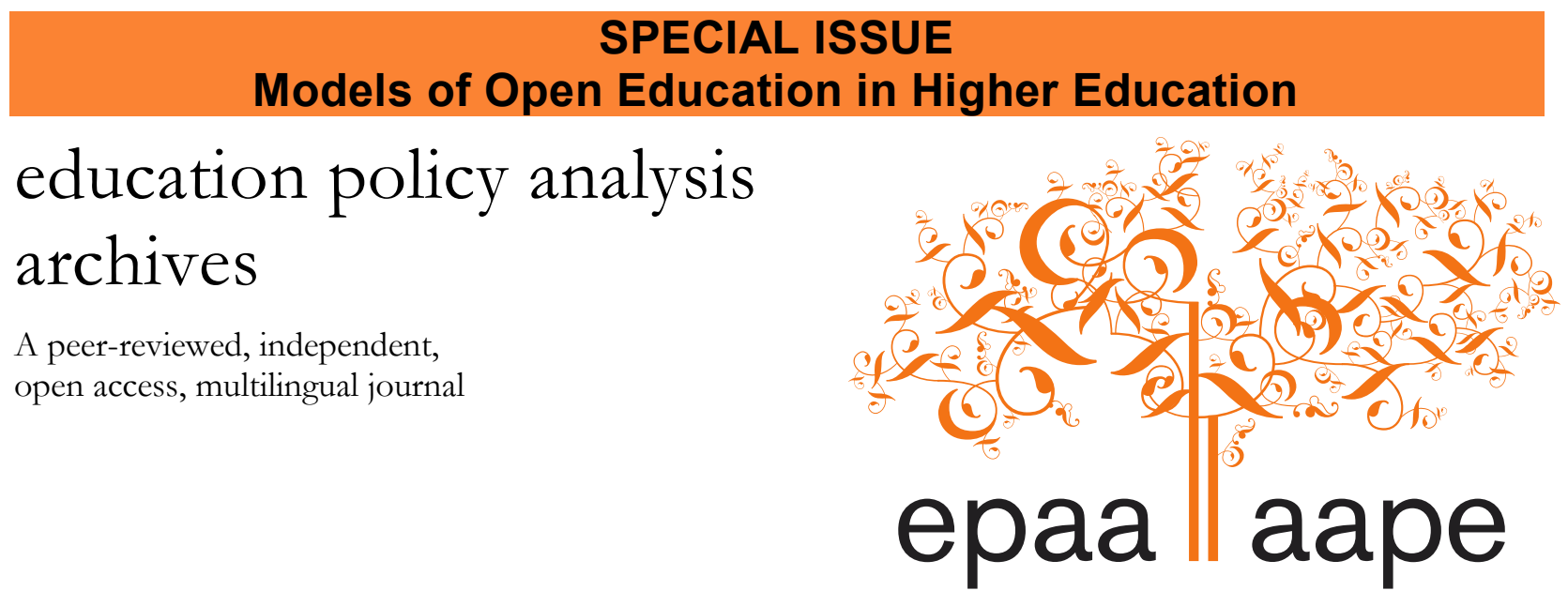

Arizona State University

\title{
The Tidewater Z-Degree and the INTRO Model for Sustaining OER Adoption
}

\author{
David Wiley \\ Lumen Learning and Brigham Young University \\ \& \\ Linda Williams \\ Daniel DeMarte \\ Tidewater Community College \\ \& \\ John Hilton \\ Brigham Young University \\ United States
}

Citation: Wiley, D., Williams, L., DeMarte, D., \& Hilton, J. (2016). The Tidewater Z-Degree and the INTRO model for sustaining OER adoption. Education Policy Analysis Archives, 23(41). http://dx.doi.org/10.14507/epaa.v23.1828 This article is part of EPAA/AAPE's Special Issue on Models of Open Education in Higher Education Guest Co-Edited by Dr. Lisa Petrides and Dr. Cynthia Jimes.

Abstract: A growing body of research confirms the financial and academic benefits that accrue to students whose faculty adopt open educational resources, or OER. While there are no content licensing costs associated with using OER, there are several real costs that must be incurred by an institution that chooses to support its faculty in adopting OER. The Z-Degree initiative at Tidewater Community College utilizes only OER for the 21 
courses, providing a pathway for students to earn an associate of science degree in business administration without ever buying a textbook. The authors introduce and illustrate the INTRO (INcreased Tuition Revenue through OER) model for sustaining the provision of OER adoption services. The adoption of OER as part of the Z-Degree decreases drop rates among Tidewater students, allowing the institution to reta in tuition revenue it would otherwise have refunded. This retained revenue provides a renewable source of funds to sustainably support the adoption of OER.

Keywords: Open Educational Resources; OER; sustainability models; student success; Z Degree; instructional materials and practices

\section{El Z-Degree de Tidewater y el modelo INTRO para la gestión sostenible en la adopción de REA}

Resumen: Un creciente cuerpo de investigaciones reafirman los beneficios económicos y académicos que reportan sobre los estudiantes universitarios el uso de recursos educativos abiertos (REA) por parte de sus docentes. Sin embargo, las instituciones que deciden apoyan a sus docentes en el uso de REA tienen que asumir una gran cantidad de costes reales, a pesar de no contar con costes asociados a las licencias de contenido. La iniciativa Z-Degree llevada a cabo por la Tidewater Community College utiliza solo REA en 21 asignaturas del Diploma de Asociado en Ciencias de Administración de Empresas, proporcionando una vía para que los estudiantes puedan obtener el título universitario sin tener que comprar un solo libro de texto. Los autores presentan e ilustran el modelo Aumento de los Ingresos por Matrículas a través de REA (INTRO, por sus siglas en inglés) para sostener la prestación de servicios que supone la adopción de los REA. La adopción de los REA como parte de la Z-Degree disminuye las tasas de abandono entre los estudiantes Tidewater, lo que permite a la institución mantener los ingresos por las matrículas. Esta retención de ingresos proporciona una fuente renovable de fondos para apoyar de forma sostenible la adopción de los REA.

Palabras-clave: Recursos Educativos Abiertos; REA; modelos de sostenibilidad; éxito de los estudiantes; Z Degree; materiales y prácticas de instrucción

\section{O Z-Degree de Tidewater e o modelo INTRO para a Adoção Sustentável dos REA}

Resumo: Um crescente corpo de pesquisa confirma os benefícios financeiros e acadêmicos que para os alunos cujos professores adotam recursos educacionais abertos, ou REA. Ainda que não há nemhum custo de licença de conteúdo associado com usar REA, sim há custos reais que devem ser incorridos por uma institucao que decide apoiar sua faculdade na adoção dos REA. A iniciativa de Z-Degree, em Tidewater College utiliza apenas REA para os vinte-uns cursos porem provendo um caminho para que os alunos ganham uma diploma de Associate's de ciencia em administração de empresas sem nunca compra um livro. Os autores apresentam e ilustram o INTRO (Increased Tuition Revenue atraves de REA) modelo para sustentar a prestação de serviços para a adoção dos REA. A adoção de REA como parte do Z-Degree diminui taxas de abandono entre os alunos de Tidewater, permitindo que a instituição retenha a receita de matrícula que em outra situação teria devolvido. Este receita retida fornece uma fonte renovável de fundos para apoiar de forma sustentável a adopção de REA.

Palavras chave: Recursos Educacionais Abertos; REA; modelos sustentáveis; sucesso de alunos; Z Degree; materiais e práticas de ensino 


\section{The Tidewater Z-Degree and the INTRO Model for Sustaining OER Adoption}

Few words are associated with more hype or confusion in the current education innovation discourse than open. The term entered the popular consciousness in the United States with the announcement of MIT's OpenCourseWare initiative (Goldberg, 2001), in which open described a generous copyright license applied to all the course materials published on the site. Over a decade later, open has been coopted by education industry marketing departments and is consequently used in a wide range of contradictory ways.

In this article we focus specifically on open educational resources, or OER. According to a popular definition published by The William and Flora Hewlett Foundation, OER are "teaching, learning, and research resources that reside in the public domain or have been released under an intellectual property license that permits their free use and re-purposing by others. Open educational resources include full courses, course materials, modules, textbooks, streaming videos, tests, software, and any other tools, materials, or techniques used to support access to knowledge" (Hewlett Foundation, 2014).

\section{OER, Student Success, and Cost Savings}

A growing body of research confirms the academic and financial benefits that accrue to students whose faculty adopt OER. As one example, Pawlyshyn, Braddlee, Casper, and Miller (2013) report on a multi-year adoption of OER in college algebra courses. In Spring 2011, Mercy College was using a popular commercial bundle comprised of a textbook and online practice system for college algebra. $48 \%$ of students passed the course that term, which was typical. During Spring 2012, Mercy launched a small OER adoption pilot, replacing the commercial bundle with OER textbooks and videos, plus an open source online practice system in six sections of college algebra. 53\% of students passed that term. By Spring 2013, Mercy had adopted the OER replacement in all 27 sections of college algebra, resulting in a pass rate of $60 \%$ that term.

Hilton, Robinson, Wiley, and Ackerman (2014) report on the amount of money saved by students whose faculty adopted OER as part of a multi-institution OER adoption project. Across seven institutions and eight courses, 2,642 students saved an average of $\$ 90.61$ per course when their faculty adopted OER.

Hilton and Laman (2012) report significant savings (\$64.30 - \$81.60) for students whose faculty adopted an open psychology textbook. Comparing the performance of these students to students taught by the same faculty one semester earlier with a commercial textbook, Hilton and Laman report that in addition to saving money, students using the open textbooks outperformed their commercial textbook-using peers on both the department final exam and in terms of final grade, in addition to withdrawing at a much lower rate.

Given the positive financial and learning impacts on students when faculty adopt OER, there is growing interest among higher education faculty and administration in adopting OER. However, this interest is mingled with concern over the costs associated with supporting effective OER adoption on their campuses.

\section{Sustaining the Adoption of OER}

Researchers and practitioners have engaged in a long and healthy debate about the possibilities of sustaining the creation and sharing of OER (Dholokai, King, \& Baraniuk, 2006; Wiley, 2006; Downes, 2007). A number of more recent studies have demonstrated successful 
financial models by which new tuition revenue resulting from registrations attributable to an institution's OER activity more than cover the costs of publishing OER (e.g., Johansen \& Wiley, 2011; Carson, Kanchanaraksa, Godding, Mulder, \& Schuwer, 2012). While questions pertaining to the sustainability of OER development are being answered, questions pertaining to the sustainability of OER adoption remain largely unasked. Finding successful models to support the ongoing creation and sharing of OER does little to benefit learners if faculty do not or cannot adopt OER.

While there are no content licensing costs associated with using open educational resources, there are several real costs that must be incurred by a faculty member or institution that chooses to adopt OER, including the costs of:

- Locating OER. There are well over half a billion openly licensed resources published on the Internet. At the time of this writing, a Google Advanced Search for the term "biology" including only results that are licensed as being "free to use share or modify" returned "About 4,660,000 results." Finding the needle that appears to be relevant for a specific use case in this haystack can be time consuming.

- Reviewing OER. After identifying OER that appear to be relevant, these must be checked for quality, accuracy, accessibility, and other desirable attributes.

- Managing open license compatibility and attribution requirements. Each open license imposes certain obligations on the user. One example is the Creative Commons Attribution License, which requires that users provide attribution to the copyright holder of the resource. Each of these requirements must be tracked and managed for all OER used in a course.

- Effectively integrating OER into teaching and learning practices. The primary distinguishing attribute of OER is the broad range of copyright permissions granted by their licenses. Many faculty require additional training in order to understand the pedagogical opportunities afforded by these permissions. Many faculty also require additional training to use common online technologies effectively in their teaching.

- Integrating OER into campus technologies like learning management systems. Most OER are provided in one or more digital formats. In order to take advantage of the permissions granted by OER, faculty will need to move them into a local learning management system or other tool with both editing and publishing capabilities. Many faculty require support in performing this initial task as well as the eventual editing and localizing tasks.

Historically, faculty have relied on publishers to provide these services in relation to commercial textbooks and educational content: curation, review, licensing and so forth. Because these needs also exist for OER, leaders at each institution that desires to support OER adoption must somehow bear the costs of providing these services to adopting faculty (or leave their faculty to go it alone). Whereas students previously paid for textbooks directly, when faculty adopt OER the institution needs to find a way to fund services supporting that adoption. These services can be provided either by adding capacity to existing libraries, centers for teaching and learning, and campus IT staff, or through outsourcing agreements. Either way, institutions that wish to promote OER adoption must find net new resources in a climate of shrinking budgets.

\section{The INTRO Model for Sustaining OER Adoption}

According to the report of the Florida Student Textbook Survey (Florida Virtual Campus, 2012), which received 22,129 responses from students enrolled at a college and/or university, 
Textbook costs continue to take a toll on students financially and academically... More than half do not have financial aid that covers any of their textbook costs... Academically, 31\% reported not registering, 35\% took fewer courses, 14\% dropped a course, and 10\% withdrew from a course [as a result of textbook costs]. (p. 2)

These data and analyses provide fertile ground for hypothesizing about the long-term sustainability of OER adoption initiatives. If some percentage of students are registering for fewer courses (in which case the institution collects no tuition) or dropping courses (in which case the institution refunds tuition) because of textbook costs, then eliminating textbook costs by adopting OER might encourage students to enroll in more courses and/or drop fewer courses. Most of the costs of teaching a course are fixed - that is, the salary of the teacher and associated facilities costs will not change whether there are 20,35 , or 50 students enrolling in a section. If a faculty member adopting OER leads to more students enrolling or fewer students dropping, this change in student behavior could translate into more tuition revenue for the institution. Were such an increase in revenue to occur, the increase could potentially be sufficient to cover the costs of providing OER adoption services to faculty. We call this sustainability model, by which increased tuition revenue covers the cost of providing OER adoption services, the INcreased Tuition Revenue through $\underline{\text { OER, or }}$ INTRO, model. In the sections that follow we describe the first known example of the INTRO model, as instantiated by an OER adoption program called the Z-Degree at Tidewater Community College.

\section{The Tidewater Community College Z-Degree Pilot}

Tidewater chose its associate of science degree in business administration to pilot as a ZDegree. The business administration degree produces the second highest number of graduates (380 graduates annually) among the college's 150 programs and is offered at all campuses. Also, the business program faculty are well known for their inspiring, innovative teaching, and one of these faculty innovators served as the faculty lead and the Z-Degree champion.

The Z-Degree utilizes only open educational resources (OER) for the 21 courses selected for the pilot. Twelve required program courses anchor the degree with the remainder consisting of a mix of electives in business administration, health/physical education, humanities, and the sciences. The elective courses were selected based upon their popularity among business program students (as indicated by the number of enrollments) and the availability of supporting OER.

The faculty team began by stripping each of the 21 courses down to the course learning outcomes and rebuilding them, matching OER to each outcome. The faculty selected OER content that was on par with or better than the quality of the existing textbook and course materials. Courses were designed consistent with college's academic and instructional design requirements, and were subjected to a strict copyright review.

In Fall 2013 (pilot year one), the 13-member faculty team, comprised of both full-time and adjunct teaching faculty from the college's four campuses, taught one section of each of the 16 firstsemester Z-courses. Although the content for Z-courses resides in Blackboard, courses were delivered in online, face-to-face, and hybrid formats. The pilot continued through the spring semester with 26 sections of Z-courses offered across all campuses. In year two of the Z-Degree pilot, the pool of faculty who will be trained to adopt and teach additional $Z$ course sections will more than double to meet student demand. 


\section{The Role of Policy in Sustaining OER Adoptions}

For the INTRO model to succeed in sustaining OER adoption services over time, OERbased courses must produce consistently lower drop rates than their historical, non-OER counterparts. As we have seen above, there are ways of using OER that do not result in decreases in drop rates. If OER were used in these less effective ways at scale, an institution might end up bearing all the costs of providing OER adoption services without seeing any of the benefits. Consequently, institutions should search for ways to insure that OER adoption produces consistent improvements in student learning outcomes.

Tidewater Community College has adopted an OER Policy (TCC, 2014) in order to promote more consistency and greater success in the use of open educational resources. The policy's stated purpose is to:

guide the use of Open Educational Resources (OER) at Tidewater Community College and to ensure OER materials are utilized with integrity. More specifically, the purpose of using OER at TCC is to improve student success through increased access and affordability and to improve teaching efficiency and effectiveness through the ability to focus, analyze, augment, and evolve course materials directly aligned to course learning outcomes. (p. 1)

The brief policy falls under the responsibility of the Vice President for Academic Affairs/Chief Academic Officer. It provides a clear definition of open educational resources (OER) and explicitly addresses licensing criteria which resources must meet to be included in an OER-based (Z-Degree) course. It deals explicitly with licensing of faculty-owned work and the importance of copyright review for all material to be included in an OER-based $\mathrm{Z}$ course. The policy requires all faculty who wish to teach an OER-based course to apply for the opportunity to do so and complete training before doing so. OER courses must be designed following college standards, using the approved templates for course outlines, syllabi, and other materials. Finally, the OER Policy commits the institution to provide faculty with analysis of learning analytics data about their courses, which faculty should use to enhance and improve the courses.

At the end of the first year of the Z-Degree pilot, Tidewater conducted a review of the courses offered as part of the Z-Degree for compliance with the policy. The review found that two of the courses did not conform with the policy (e.g., adopting non-OER in place of OER). Consequently, these courses are being completely redesigned before being offered again as part of the Z-Degree. Data from these two courses are excluded from the analyses reported in the next section.

\section{Initial Results from the Z-Degree Pilot}

In the fall semester of 2013, 303 students enrolled in Z sections of courses at Tidewater Community College. Another 12,574 enrolled in non- $Z$ sections of those same courses. Of those enrollments, 8 students dropped from $Z$ sections and 468 students dropped from non- $Z$ sections. As shown in Table 1, the drop rate for $Z$ sections was $2.64 \%$ and the drop rate for non- $Z$ sections was $3.72 \%$. 
Table 1

Drop Rates for Fall Term 2013

\begin{tabular}{lccc}
\hline Section Type & Enrollments & Drops & Drop Rate \\
\hline Non-Z & 12574 & 468 & $3.72 \%$ \\
$Z$ & 303 & 8 & $2.64 \%$
\end{tabular}

A $z$ test of proportions confirms that the difference in drop rates is statistically significant $(z$ $=3.84, \mathrm{p}<0.01$ ), with students in courses adopting OER instead of commercial materials dropping at a lower rate.

In the spring semester of 2014, 450 students enrolled in Z sections of courses at Tidewater Community College. Another 10,658 enrolled in non-Z sections of those same courses. Of those enrollments, 13 students dropped from $Z$ sections and 362 students dropped from non- $Z$ sections. As shown in Table 2, the drop rate for $Z$ sections was $2.89 \%$ and the drop rate for non- $Z$ sections was $3.40 \%$.

Table 2

Drop Rates for Spring Term 2013

\begin{tabular}{lccc}
\hline Section Type & Enrollments & Drops & Drop Rate \\
\hline Non-Z & 10658 & 362 & $3.40 \%$ \\
$Z$ & 450 & 13 & $2.89 \%$ \\
\hline
\end{tabular}

The drop rate is once again lower for courses adopting OER, and a $z$ test of proportions indicates that the difference in drop rates is statistically significant $(z=2.24, p=0.025)$.

The overall drop rates for the first year of the pilot were $2.79 \%$ for $Z$ sections, and 3.57 for non-Z sections, as shown in Table 3.

Table 3

Aggregate Drop Rates for Fall 2012 and Spring 2013 Terms

\begin{tabular}{lccc}
\hline Section Type & Enrollments & Drops & Drop Rate \\
\hline Non-Z & 23232 & 830 & $3.57 \%$ \\
$Z$ & 753 & 21 & $2.79 \%$
\end{tabular}

A $z$ test of proportions confirms that the difference in drop rates for the academic year is statistically significant $(z=4.40, \mathrm{p}<0.01)$, with students in courses adopting OER instead of commercial materials dropping at a lower rate. 


\section{Finances and the Tidewater Implementation of the INTRO Model}

The previous discussions lay the groundwork for providing preliminary answers to sustainability questions with regard to the Tidewater Z-Degree and the INTRO model. To summarize data presented above and provide the final pieces necessary for calculating increased revenue attributable to OER adoption:

- The difference in drop rates between the $Z$ sections and non- $Z$ sections of the business administration courses and associated general education electives offered during the 20132014 pilot year was $0.78 \%$.

- Enrollments in non-Z sections of these courses totaled 23,232 during the pilot.

- Tuition and fees at Tidewater are currently set at $\$ 164.35$ per hour for in-state students and $\$ 358.95$ per hour for out-of-state students.

- Enrollments for fall and spring terms at Tidewater split approximately as $89 \%$ in-state students and $11 \%$ out-of-state students.

If all sections of relevant non-Z courses became $Z$ sections - in other words, if all faculty teaching in the Business Administration program and its associated general education courses adopted OER in a manner consistent with the institutional policy - Tidewater Community College could expect to prevent 182 drops from occurring during Fall and Spring terms. Using the in-state and out-of-state enrollment percentages, tuition and fees data per credit hour for three credit courses, and this number we arrive at the annual INcreased Tuition Revenue through OER, or INTRO figure:

$(182 * .89 * \$ 164.35 * 3)$ in-state $+(182 * .11 * \$ 358.95 * 3)$ out-of-state $=\$ 101,422.78$ annual INTRO

This increase in revenue coinciding with OER adoption represents a source from which Tidewater, or any other institution, might fund ongoing OER adoption support services.

\section{Future Research}

Like much research, this initial work and model building raises more questions than it answers. From a financial perspective, at least two major questions need to be explored in further detail before the model can be broadly applied. The first acknowledges the peculiar accounting practices of universities, which often place funding from different sources into different silos, allowing money from specific silos to be spent only for specific purposes. The question relevant to the current work is, what percentage of annual INTRO could actually be available to spend on OER adoption activities? This is entirely a matter of local policy and will vary from institution to institution. The second acknowledges the existence of performance-based funding models that apply to institutions like Tidewater. Preventing students from dropping courses will help more students achieve performance milestones that, in turn, will unlock additional funding for institutions. What will this growth in funding look like? And which silos will these dollars flow into? Again, these are all matters of local policy and will vary from institution to institution.

A number of questions also surface from a research perspective. The first has to do with how course drops are counted. For this study, drops were calculated by subtracting the number of students enrolled on the census date from the number enrolled on the first day of class. This manner of measuring drops does not fully account for cases where students drop one section (e.g., a non-Z 
section) and enroll in another section (e.g., a $Z$ section) during the same term. For example, if 10 students dropped a $Z$ section of a course, then another 10 students dropped a non- $Z$ section of a course and joined the $Z$ section which was dropped by the original 10 , the non- $Z$ section would show drops in our calculation but the $Z$ section would not. A calculation that traces individual students who drop and evaluates their later behavior would provide additional nuance to the drop measure.

Another research question has to do with the difference in drop rates between Fall and Spring terms. While the non-Z section drop rate in both terms was higher than the $\mathrm{Z}$ section drop rate, it was only statistically significantly higher in Fall. Are these fluctuations in drop rate seasonal? Are they noise that will stabilize over time? Additional data should be collected and analyzed about seasonal differences in the drop rate.

Finally, we cannot be certain that additional faculty at Tidewater who adopt OER will see the same results as pilot faculty. The institution did not use a randomization technique for selecting faculty to participate in the pilot, and consequently pilot faculty may be systematically different from non-pilot faculty in some important way. Perhaps this systematic difference resulted in changes to the drop rate in their courses that are not representative of the changes the broader faculty population would see. The pilot faculty may have had better or worse results than a broader population of adopters would have. The Tidewater OER Policy requirement for faculty who want to teach $\mathrm{Z}$ sections to receive training beforehand may moderate some of the natural variance in population. If this finding is replicated in other studies, it may lead to a source of funding that allows greater adoption of OER.

\section{Conclusion}

The adoption of OER instead of commercial textbooks by faculty has been shown to result in significant cost savings and meaningful academic gains for students. However, successful adoption and use of OER requires institutions to provide a range of supports to adopting faculty. Because the cost of providing these supports may impede the beneficial adoption of OER, there is a need to identify potential ways of funding the provision of these services. This article introduced the INTRO model, demonstrating both that OER adoption lowers the drop rate among students in those OER-adopting courses (improving their academic success while decreasing their cost to attend) and that the decrease in tuition refunds associated with the decrease in drops amounts to a substantial new source of revenue for the institution. In the case of Tidewater Community College, using OER across a single degree program could increase its tuition revenue by over $\$ 100,000$ per year - while improving student outcomes and decreasing the cost to attend college.

\section{References}

Carson, S., Kanchanaraksa, S., Godding, I., Mulder, F., \& Schuwer, R. (2012). Impact of OpenCourseWare Publication on Higher Education Participation and Student Recruitment. International Review of Research on Distance and Open Learning, 13(4). http://www.irrodl.org/index.php/irrodl/article/view/1238/2283

Dholakia, U. M., King, W. J., \& Baraniuk, R. (2006). What Makes an Open Education Program Sustainable? The Case of Connexions. Whitepaper commissioned by OECD. Retrieved from http://www.oecd.org/edu/ceri/36781781.pdf

Downes, S. (2007). Models for Sustainable Open Educational Resources. Interdisciplinary Journal of Knowledge and Learning Objects (3). http://ijklo.org/Volume3/IJKLOv3p029-044Downes.pdf 
Florida Virtual Campus (2012). Florida Student Textbook Survey. Retrieved from http://www.openaccesstextbooks.org/pdf/2012 Florida Student Textbook Survey.pdf

Goldberg, C. (2001, April 4). Auditing Classes at M.I.T., on the Web and Free. New York Times. . Retrieved from http://www.nytimes.com/2001/04/04/us/auditing-classes-at-mit-on-theweb-and-free.html

Hewlett Foundation (2014). Open Educational Resources. Retrieved from http://www.hewlett.org/programs/education/open-educational-resources

Hilton, J. \& Laman, C. (2012). One college's use of an open psychology textbook. Open Learning. 27(3), pp. 265-272.

Hilton, J., Robinson T. J., Wiley, D., A., \& Ackerman, J. (2014). Cost-Savings Achieved in Two Semesters Through the Adoption of Open Educational Resources. International Review of Research on Distance and Open Learning, 15(2). http://www.irrodl.org/index.php/irrodl/article/view/1700/2833

Johansen, J. \& Wiley, D. (2011). A sustainable model for opencourseware development. Educational Technology Research \& Development, 59(3), p. 369-382. DOI: 10.1007/s11423-010-9160-7

Pawlyshyn, N., Braddlee, Casper, L., \& Miller, H. (2013). Adopting OER: A Case Study of CrossInstitutional Collaboration and Innovation. Educause Review.

Tidewater Community College (TCC). (2014). Use of Open Educational Resources Policy. https://web.tcc.edu/policies/2000/2108-UseofOpenEducationalResources.pdf

Wiley, D. (2006). On the sustainability of open educational resource initiatives in higher education. Whitepaper commissioned by OECD. Retrieved from: http://www.oecd.org/dataoecd/33/9/38645447.pdf 


\section{About the Author}

\section{David Wiley}

Lumen Learning and Brigham Young University

david.wiley@lumenlearning.com

Dr. David Wiley is Chief Academic Officer of Lumen Learning and adjunct faculty in Brigham Young University's graduate program in Instructional Psychology and Technology, where he leads the Open Education Group. Dr. Wiley has received numerous recognitions for his work, including an NSF CAREER grant, an appointment as Nonresident Fellow in the Center for Internet and Society at Stanford Law School, and a Shuttleworth Fellowship.

\section{Linda S. Williams}

Professor, Business Management \& Administration, Tidewater Community College lswilliams@,tcc.edu

Linda Williams, MBA, MSA, is a Professor of Business Management \& Administration at Tidewater Community College. She served as the faculty lead for Tidewater's Z Degree and continues to lead OER initiatives at the college to expand $Z$ course offerings and launch additional $\mathrm{Z}$ Degrees.

\section{Daniel DeMarte}

Vice President for Academic Affairs, Tidewater Community College ddmarte@,tcc.edu

Daniel DeMarte is the vice president for academic affairs at Tidewater Community College. He serves as the lead for Tidewater's Z-Degree and provides support to faculty in achieving the full potential of Open Educational Resources (OER).

\section{John Hilton}

Religious Education, Brigham Young University johnhiltoniii@,byu.edu John Hilton III is an Assistant Professor of Religious Education at Brigham Young University. He studies the efficacy of Open Educational Resources as well as other topics in pedagogy.

\section{About the Co-Guest Editors}

\section{Lisa A. Petrides}

Institute for the Study of Knowledge Management in Education lisa@iskme.org Lisa Petrides, Ph.D. is CEO and founder of the Institute for the Study of Knowledge Management in Education (ISKME). A former professor in the Department of Organization and Leadership at Columbia University, Teachers College, her research and teaching interests include information science, decision-making, and issues of access and equity in education. Petrides also leads OER Commons (www.oercommons.org), a digital public library of open educational resources, and a collaboration platform that supports and facilitates the creation, sharing, and modification of open educational resources. Petrides received her Ph.D. from Stanford University. 


\section{Cynthia M. Jimes}

Institute for the Study of Knowledge Management in Education

cynthia@iskme.org

Cynthia Jimes, Ph.D., is Director of Research at the Institute for the Study of Knowledge Management in Education (ISKME), where she has led international projects over the past ten years focusing on the use and impact of open educational resources on teaching and learning. While living in Sweden and the Netherlands from 1995 to 2004, she worked in both the private and public sectors, holding positions in research consulting, teaching high school and college, and obtaining her Ph.D. in Information Science from Uppsala University in Sweden.

\section{SPECIAL ISSUE \\ Models of Open Education in Higher Education education policy analysis archives}

Volume 24 Number $41 \quad$ March 28, 2016

ISSN 1068-2341

\section{(c)}

SOMEFIIGHISRESERVED Readers are free to copy, display, and distribute this article, as long as the work is attributed to the author(s) and Education Policy Analysis Archives, it is distributed for noncommercial purposes only, and no alteration or transformation is made in the work. More details of this Creative Commons license are available at http://creativecommons.org/licenses/by-nc-sa/3.0/. All other uses must be approved by the author(s) or EPAA. EPAA is published by the Mary Lou Fulton Institute and Graduate School of Education at Arizona State University Articles are indexed in CIRC (Clasificación Integrada de Revistas Científicas, Spain), DIALNET (Spain), Directory of Open Access Journals, EBSCO Education Research Complete, ERIC, Education Full Text (H.W. Wilson), QUALIS A2 (Brazil), SCImago Journal Rank; SCOPUS, SOCOLAR (China).

Please contribute commentaries at http://epaa.info/wordpress/ and send errata notes to Gustavo E. Fischman fischman@asu.edu

Join EPAA's Facebook community at https://www.facebook.com/EPAAAAPE and Twitter feed@epaa_aape. 


\section{education policy analysis archives editorial board}

Lead Editor: Audrey Amrein-Beardsley (Arizona State University)

Executive Editor: Gustavo E. Fischman (Arizona State University) Associate Editors: Sherman Dorn, David R. Garcia, Oscar Jimenez-Castellanos,

Eugene Judson, Jeanne M. Powers (Arizona State University)

Cristina Alfaro San Diego State

University

Gary Anderson New York

University

Michael W. Apple University of

Wisconsin, Madison

Jeff Bale OISE, University of

Toronto, Canada

Aaron Bevanot SUNY Albany

David C. Berliner Arizona

State University

Henry Braun Boston College

Casey Cobb University of

Connecticut

Arnold Danzig San Jose State

University

Linda Darling-Hammond

Stanford University

Elizabeth H. DeBray University of

Georgia

Chad d'Entremont Rennie Center

for Education Research \& Policy

John Diamond University of

Wisconsin, Madison

Matthew Di Carlo Albert Shanker Institute

Michael J. Dumas University of California, Berkeley

Kathy Escamilla University of

Colorado, Boulder

Melissa Lynn Freeman Adams

State College

Rachael Gabriel

University of Connecticut

Amy Garrett Dikkers University of North Carolina, Wilmington

Gene V Glass Arizona

State University
Ronald Glass University of

California, Santa Cruz

Jacob P. K. Gross University of Louisville

Eric M. Haas WestEd

Julian Vasquez Heilig California

State University, Sacramento

Kimberly Kappler Hewitt University of North Carolina Greensboro

Aimee Howley Ohio University

Steve Klees University of Maryland

Jaekyung Lee

SUNY Buffalo

Jessica Nina Lester

Indiana University

Amanda E. Lewis University of Illinois, Chicago

Chad R. Lochmiller Indiana

University

Christopher Lubienski University of Illinois, Urbana-Champaign

Sarah Lubienski University of Illinois, Urbana-Champaign

William J. Mathis University of Colorado, Boulder

Michele S. Moses University of Colorado, Boulder

Julianne Moss Deakin

University, Australia

Sharon Nichols University of Texas, San Antonio

Eric Parsons University of

Missouri-Columbia

Susan L. Robertson Bristol

University, UK

Gloria M. Rodriguez

University of California, Davis
R. Anthony Rolle University of Houston

A. G. Rud Washington State University

Patricia Sánchez University of University of Texas, San Antonio Janelle Scott University of California, Berkeley

Jack Schneider College of the Holy Cross

Noah Sobe Loyola University

Nelly P. Stromquist University of Maryland

Benjamin Superfine University of Illinois, Chicago

Maria Teresa Tatto

Michigan State University

Adai Tefera Virginia

Commonwealth University

Tina Trujillo University of California, Berkeley

Federico R. Waitoller University of Illinois, Chicago

Larisa Warhol University of Connecticut

John Weathers University of Colorado, Colorado Springs

Kevin Welner University of Colorado, Boulder

Terrence G. Wiley Center for Applied Linguistics

John Willinsky

Stanford University

Jennifer R. Wolgemuth

University of South Florida

Kyo Yamashiro Claremont Graduate University 


\section{archivos analíticos de políticas educativas consejo editorial}

Editor Ejecutivo: Gustavo E. Fischman (Arizona State University)

Editores Asociados: Armando Alcántara Santuario (Universidad Nacional Autónoma de México), Jason Beech, (Universidad de San Andrés), Antonio Luzon, Universidad de Granada

Claudio Almonacid

Universidad Metropolitana de

Ciencias de la Educación, Chile

Miguel Ángel Arias Ortega

Universidad Autónoma de la

Ciudad de México

Xavier Besalú Costa

Universitat de Girona, España

Xavier Bonal Sarro Universidad

Autónoma de Barcelona, España

Antonio Bolívar Boitia

Universidad de Granada, España

José Joaquín Brunner Universidad

Diego Portales, Chile

Damián Canales Sánchez

Instituto Nacional para la

Evaluación de la Educación, México

Gabriela de la Cruz Flores

Universidad Nacional Autónoma de México

Marco Antonio Delgado Fuentes

Universidad Iberoamericana,

México

Inés Dussel, DIE-CINVESTAV, México

Pedro Flores Crespo Universidad

Iberoamericana, México

Ana María García de Fanelli

Centro de Estudios de Estado y

Sociedad (CEDES) CONICET,

Argentina
Juan Carlos González Faraco

Universidad de Huelva, España

María Clemente Linuesa

Universidad de Salamanca, España

Jaume Martínez Bonafé

Universitat de València, España

Alejandro Márquez Jiménez

Instituto de Investigaciones sobre la

Universidad y la Educación, UNAM,

México

María Guadalupe Olivier Tellez,

Universidad Pedagógica Nacional, México

Miguel Pereyra Universidad de

Granada, España

Mónica Pini Universidad Nacional de San Martín, Argentina

Omar Orlando Pulido Chaves

Instituto para la Investigación

Educativa y el Desarrollo Pedagógico (IDEP)

José Luis Ramírez Romero

Universidad Autónoma de Sonora,

México

Paula Razquin Universidad de San

Andrés, Argentina

José Ignacio Rivas Flores

Universidad de Málaga, España
Miriam Rodríguez Vargas

Universidad Autónoma de

Tamaulipas, México

José Gregorio Rodríguez

Universidad Nacional de

Colombia, Colombia

Mario Rueda Beltrán Instituto

de Investigaciones sobre la

Universidad y la Educación,

UNAM, México

José Luis San Fabián Maroto

Universidad de Oviedo,

España

Jurjo Torres Santomé,

Universidad de la Coruña, España

Yengny Marisol Silva Laya

Universidad Iberoamericana,

México

Juan Carlos Tedesco

Universidad Nacional de San

Martín, Argentina

Ernesto Treviño Ronzón

Universidad Veracruzana, México

Ernesto Treviño Villarreal

Universidad Diego Portales

Santiago, Chile

Antoni Verger Planells

Universidad Autónoma de

Barcelona, España

Catalina Wainerman

Universidad de San Andrés, Argentina

Juan Carlos Yáñez Velazco

Universidad de Colima, México 


\section{arquivos analíticos de políticas educativas conselho editorial}

Editor Executivo: Gustavo E. Fischman (Arizona State University) Editoras Associadas: Geovana Mendonça Lunardi Mendes (Universidade do Estado de Santa Catarina), Marcia Pletsch, Sandra Regina Sales (Universidade Federal Rural do Rio de Janeiro)

\author{
Almerindo Afonso \\ Universidade do Minho \\ Portugal \\ Rosanna Maria Barros Sá \\ Universidade do Algarve \\ Portugal

\section{Maria Helena Bonilla \\ Universidade Federal da Bahia \\ Brasil}

Rosa Maria Bueno Fischer

Universidade Federal do Rio Grande

do Sul, Brasil

Alice Casimiro Lopes

Universidade do Estado do Rio de

Janeiro, Brasil

\section{Suzana Feldens Schwertner}

Centro Universitário Univates

Brasil

Flávia Miller Naethe Motta

Universidade Federal Rural do Rio de Janeiro, Brasil
Alexandre Fernandez Vaz

Universidade Federal de Santa

Catarina, Brasil

\section{Regina Célia Linhares Hostins \\ Universidade do Vale do Itajaí, Brasil}

\section{Alfredo Macedo Gomes \\ Universidade Federal de Pernambuco \\ Brasil}

\section{Jefferson Mainardes}

Universidade Estadual de Ponta

Grossa, Brasil

\section{Jader Janer Moreira Lopes}

Universidade Federal Fluminense e

Universidade Federal de Juiz de Fora, Brasil

\section{Debora Nunes}

Universidade Federal do Rio Grande do Norte, Brasil

\section{Alda Junqueira Marin \\ Pontifícia Universidade Católica de São Paulo, Brasil}

Dalila Andrade Oliveira

Universidade Federal de Minas

Gerais, Brasil
José Augusto Pacheco

Universidade do Minho, Portugal

\section{Jane Paiva}

Universidade do Estado do Rio de Janeiro, Brasil

\section{Paulo Alberto Santos Vieira}

Universidade do Estado de Mato Grosso, Brasil

Fabiany de Cássia Tavares Silva Universidade Federal do Mato

Grosso do Sul, Brasil

\section{António Teodoro}

Universidade Lusófona

Portugal

\section{Lílian do Valle}

Universidade do Estado do Rio de Janeiro, Brasil

\author{
Alfredo Veiga-Neto \\ Universidade Federal do Rio Grande \\ do Sul, Brasil
}

